\title{
PENINGKATAN KEMAMPUAN MEMBACA KALIMAT DENGAN AKSARA LAMPUNG MELALUI PENERAPAN MODEL PEMBELAJARAN LITERASI INFORMASI SISWA KELAS IV SD NEGERI 04 TANJUNG AMAN KOTABUMI TAHUN PELAJARAN 2020/2021
}

\author{
Masitoh $^{1}$ \\ masitohstkipm64@gmail.com
}

\section{Universitas Muhammadiyah Kotabumi}

\begin{abstract}
The learning material in Lampung language is quite difficult to learn by elementary students. One of those were the material Lampung's script reading. The teacher should be able to carry out the planning and learning experiences that will be provided to students properly. The teacher should be good at using a learning model that can improve students' reading ability and motivation to learn Lampung's script. One of those models that can be use by the teacher were information literacy learning model.The problem of this research isthe improvement of students' reading abilityto read Lampung's script sentences through the implemenation of information literacy learning model at fourth grade students of SDN 04 Tanjung Aman Kotabumi in academic year2020/2021 The research objective was to describe the improvement of students' reading ability to read Lampung's script sentences through the implemenation of information literacy learning model at fourth grade students of SDN 04 Tanjung Aman Kotabumi in academic year 2020/2021. Classroom Action Research was applied in this research that devided into 4 steps, i.e; planning, implementing, observing and reflection. For the implementing steps was carried out in three cycle. Based on the implementation that already applied in this reserach, it could be conclude that the application of the information literacy learning model could improve the students learning process by reading Lampung's script sentences. It could be seen based on the result as follows: Lampung's script sentences in cycle $I=70 \%$ (22 students), cycle II $=85 \%$ (26 students), and cycle III=98\% (30 students). (2) The percentage of the model application of learning information in cycle $I=70 \%$, cycle $I I=83 \%$, and cycle $I I I=95 \%$.
\end{abstract}

Key Words: information literacy learning model, reading Lampung's script sentences

Abstrak: Materi dalam pembelajaran bahasa Lampung cukup sukar dipelajari anak SD, di antaranya yaitu materi membaca dengan tulisan Lampung. Pendidik harus selalu berupaya menjalankan kegiatan proses belajar mengajar untuk peserta didik dengan sungguhsungguh. Seorang pendidik harus pandai menggunakan perangkat pembelajaran dengan baik sehingga kemampuan membaca dan kemauan belajar peserta didiknya untuk belajar aksara Lampung menjadi meningkat. Salah satu model pembalajaran itu adalah model pembelajaran literasi informasi. Dari penjelasan di muka masalah penelitian yang dapat dikemukakan adalah: "Peningkatan kemampuan membaca kalimat dengan aksara Lampung melalui penerapan model pembelajaran literasi informasi siswa kelas IV SDN 04 Tanjung Aman Kotabumi tahun pelajaran 2020/2021." Tujuan penelitiannya adalah untuk mendeskripsikan peningkatan kemampuan membaca kalimat dengan aksara Lampung melalui penerapan model pembelajaran literasi informasi siswa kelas IV SDN 04 Tanjung Aman Kotabumi tahun pelajaran 2020/2021. Adapun metode yang digunakan dalam penelitian ini adalah metode penelitian tindakan kelas. Pelaksanaan tindakan kelas berupa 
siklus-siklus (terdiri atas 3 siklus) yang memuat skenario pembelajaran (perencanaan), deskripsi pembelajaran (pelaksanaan), sajian hasil data (observasi), dan refleksi. Hasil penelitian menunjukan bahwa terjadi peningkatan kemampuan membaca dengan aksara Lampung melalui penerapan Aman tahun pelajaran 2020/2021. Hal ini dapat dilihat pada hasil penelitian yang telah dilakukan, yaitu sebagai berikut. Pertama, persentase ketuntasan penilaian proses kemampuan membaca kalimat dengan aksara Lampung siswa selas IV SD Negeri 04 Tanjung Aman Kotabumi tahun pelajaran 2020/2021pada siklus I= 70\% (22 siswa), Siklus II $=85 \%$ (26 siswa), dan Siklus $\mathrm{III}=98 \%$ (30 siswa). Kedua,persentase penerapan model pembelajaran literasi informasi siswa kelas IV SDN 04 Kotabumi tahun pelajaran 2020/2021 pada siklus I $=70 \%$, siklus II $=83 \%$, dan siklus III $=95 \%$.

Kata Kunci: model pembelajaran literasi informasi, membaca kalimat aksara Lampung

\section{PENDAHULUAN}

Aksara Lampung merupakan aset daerah yang perlu dijaga dari kepunahan. Untuk melestarikan bahasa Lampung, Pemerintah Daerah Provinsi Lampung telah membuat payung hukum yang me-ngikat dan menguatkan pentingnya pe-ngajaran bahasa Lampung dipelajari di sekolah. "Peraturan Gubernur Lampung No. 39 tahun 20014 pun menjadi angin segar dalam upaya pelestarian bahasa ini. Peraturan tersebut memuat tentang pelestarian dan pembelajaran bahasa dan sastra Lampung sebagai mata pelajaran wajib yang masuk dalam muatan local diajarkan dari jenjang pendidikan SD, SMP, SMA/SMK, sampai perguruan tinggi” (Agustina, 2016).

Aksara Lampung merupakan salah satu bukti telah majunya peradaban anak bangsa yang perlu dijaga dan dilestarikan agar tidak punah ditelan jaman. Cara yang harus dilakukan adalah dengan mem- pelajari dan mendalami bahasa Lampung. Bahasa Lampung memiliki dua dialek besar, yaitu dialek A dan O. Masing-masing dialek memiliki jumlah penutur yang sama banyak dan kedua dialek itu harus dipahami peserta didik secara bersamaan. Hal ini yang menyebabkan bahasa Lampung sukar dipahami oleh peserta didik (Masitoh, 2010). Salah satu materi pelajaran bahasa Lampung yang cukup sukar untuk dipelajari adalah membaca dengan aksara Lampung. Hal ini dapat terjadi karena kegiatan membaca aksara Lampung akan melibatkan beberapa unsur bahasa yang meliputi tanda baca, fonologi, morfologi, dan semantik yang merupakan kajian bahasa tentang proses terbentuknya sebuah kalimat. Hal ini sejalan dengan pendapat Alwi (2003) yang menjelaskan bahwa kalimat dalam wujud tulisan dimulai dengan menggunakan huruf kapital yang di akhiri dengan tanda titik, tanya, seru; sementara di dalamnya berisikan kata, frasa, klausa, semantik disertakan pula 
Peningkatan Kemampuan Membaca Kalimat dengan Aksara Lampung melalui Penerapan Model Pembelajaran Literasi Informasi Siswa Kelas IV SD Negeri 04 Tanjung Aman Kotabumi Tahun Pelajaran 2020/2021 (Masitoh)

berbagai tanda baca seperti tanda koma (,), titik dua(:), titk koma (;), tanda pisah (-), dan spasi yang diakhiri dengan tanda titik (.), tanya(?), dan seru (-).

Pelajaran membaca kalimat dengan aksara Lampung akan diterima saat siswa di kelas IV. Siswa SD kelas IV umur mereka diperkirakan antara 10 s.d. 11 tahun dan masuk dalam kategori kelas tinggi sekolah dasar. Walaupun termasuk dalam kelas tinggi, menurut Winarno (2020) pelajaran membaca kalimat dengan aksara Lampung yang diberikan pada tataran kalimat tunggal, terdiri atas satu klausa. Hal ini berarti unsur wajib hanya terdiri atas subjek, predikat, dan objek, dapat ditambah keterangan hanya ada satu dan merupakan satu kesatuan. Contohnya: Nyak ghadu mengan 'Saya sudah makan'.

Pendidik harus selalu berupaya menjalankan kegiatan proses belajar mengajar untuk peserta didik dengan sungguh-sungguh. Seorang pendidik harus pandai menggunakan perangkat pembelajaran dengan baik sehingga kemampuan membaca dan kemauan belajar peserta didiknya untuk belajar aksara Lampung menjadi meningkat. Pendidik juga dapat memanfaatkan perangkat pembelajaran yang ada di lingkungan siswa berada sehingga sumber belajar yang akan dipelajari jelas bentuknya dan lebih bermanfaat bagi peserta. Dengan demikian, membuat mereka lebih bersemangat untuk memperoleh pengalaman belajarnya.

Siswa kelas IV SDN 04 Tanjung Aman masih sukar melakukan kegiatan membaca dengan aksara Lampung. Sukarnya membaca kalimat dengan aksara Lampung ini terungkap pada waktu pembelajaran aksara Lampung dilakukan. Hal ini terbukti dari nilai kemampuan membaca dengan aksara Lampung yang mereka peroleh $50 \%$ belum mencapai nilai $\mathrm{KKM}=70$. Oleh karena itu, kegiatan belajar membaca kalimat dengan aksara Lampung di SD Negeri 04 Tanjung Aman harus dilakukan teru-menerus. Untuk mengatasi hal tersebut seorang pendidik harus pandai memanfaatkan perangkat pembelajaran yang menunjang kemampuan membaca dan motivasi peserta didik belajar aksara Lampung. Salah satu model pembalajaran, yaitu model pembelajaran literasi informasi.

Model pembelajaran literasi adalah model pembelajaran yang memfokuskan pada acuan yang terkonsep dipakai sebagai pedoman untuk melakukan kegiatan di kelas atau pembelajaran tutorial. Hal ini dapat memaksimalkan kemampuan yang berhubungan dengan berpikir, menyimak, berbicara, membaca, dan menulis sehingga peserta didik memiliki ke-mampuan berbahasa yang baik untuk me-layani tuntutan masyarakat modern. Lebih khusus lagi dapat dijelaskan bahwa model pembelajaran literasi informasi menuntut 
agar peserta didik belajar dengan aktif dan mencari bahan materi pelalajaran dari berbagai sumber. Hal ini sejalan dengan pendapat Sigmon yang dikutip Kusuma (2010) bahwa model pembelajaran literasi informasi memiliki pengaruh yang lebih baik dalam mengembangkan kemampuan peserta didik.

Berdasarkan penjelasan di atas, akan dilakukan penelitian dengan judul "Peningkatan Kemampuan Membaca Kalimat dengan Aksara Lampung melalui Penerapan Model Pembelajaran Literasi Informasi Siswa Kelas IV SD Negeri 04 Tanjung Aman Kotabumi Tahun Pelajaran 2020/2021. Adapun penelitian ini memiliki tujuan memberi gambaran peningkatan kemampuan membaca ka-limat dengan aksara Lampung melalui penerapan model pembelajaran literasi informasi siswa kelas IV SD Negeri 04 Tanjung Aman Kotabumi tahun pelajaran 2020/2021.

\section{A. METODE}

Metode yang digunakan dalam penelitian ini adalah penelitian tindakan kelas (PTK) berdaur/siklus. Arikunto (2011) menyatakan bahwa "PTK adalah penelitian tindakan yang dilakukan dengan tujuan memperbaiki mutu praktik pembelajaran di kelas." Hal yang sama dinyatakan oleh Suwandi (2011) bahwa "PTK merupakan suatu pencermatan terhadap kegiatan belajar berupa sebuah tindakan yang sengaja dimunculkan dan terjadi dalam sebuah kelas secara bersamaan. Tindakan tersebut diberikan oleh pendidik atau dengan arahan pendidik yang dilakukan oleh peserta didik. "Prinsip utama dalam PTK adalah adanya pemberian tindakan yang diaplikasikan dalam siklus-siklus yang berkelanjutan.

Tindakan penelitian ini dilaksanakan pada bulan Februari s.d. Oktober 2020. Kegiatan penelitian dilaksanakan di kelas IV Sekolah Dasar Negeri 04 Tanjung Aman Kotabumi yang berjumlah 93 siswa, yaitu kelas IVA, IVB, dan IVC yang masing-masing terdiri atas 31 siswa. Langkah-langkah pelaksanaan penelitian tindakan kelas menurut Sumarno (2020), yaitu "perencanaan tindakan (skenario pembelajaran), pelaksanaan tindakan (deskripsi proses pembelajaran), pelaksanaan observasi (sajian analisis data), dan refleksi (kajian terhadap indikator kinerja terhadap hasil dan proses pembelajaran dan analisis kritis hasil tiap siklus)."Ada tiga siklus dalam pelaksanaan tindakannya. Hal-hal yang berkaitan dengan perangkat pembelajaran, seperti kurikulum, model pembelajaran, pengamat, rencana pelaksaan pembelajara, lembarkerja siswa, serta alat tes maupun nontes perlu dilakukan 
Peningkatan Kemampuan Membaca Kalimat dengan Aksara Lampung melalui Penerapan Model Pembelajaran Literasi Informasi Siswa Kelas IV SD Negeri 04 Tanjung Aman Kotabumi Tahun Pelajaran 2020/2021 (Masitoh)

dan disiapkan dengan matang. Saat kegiatan pembelajaran berlangsung, siswa diharapkan mengikuti proses pelaksanaan penelitian yang dilakukan guru.

Adapun alat untuk mengumpulkan data penelitian berupa teks wawancara, buku pengamatan kegiatan pendidik dan peserta, soal tes membaca aksara Lampung. Tarigan (2010) mengatakan: "Hal-hal yang akan dievaluasi dalam penilaian proses membaca yaitu pelafalan, intonasi, kelancaran, dan pemahaman." Data yang diperoleh dapat berupa penjelasan-penjelasan dan angkaangka. Proses pembelajaran penelitian tindakan kelas terdiri atas kegiatan awal (pengajar menjelaskan tujuan pembelajaran yang akan dicapai); inti (pengajar mempraktikkan model pembelajaran literasi informasi); dan akhir (pengajar menilai peserta didik yaitu nilai kemampuan membaca kalimat dengan aksara Lampung).

Penilaian proses pembelajaran dapat dilihat dari sikap peserta didik ketika mengikuti kegiatan pembelajaran. Sikap bermula dari perasaan suka atau tidak suka yang terkait dengan kecenderungan seseorang dalam merespons sesuatu/objek. Sikap juga merupakan ekspresi dari nilai-nilai atau pandangan hidup yang dimiliki seseorang. Sikap dapat dibentuk sehingga terjadi perilaku atau tindakan yang diinginkan.
Suwandi S., (2011) memaparkan bahwa sikap bermula dari perasaan yang terkait dengan kecenderungan seseorang dalam merespons sesuatu atau objek. Sikap juga suatu ekspresi dari nilai-nilai atau pandangan hidup yang dimiliki oleh seseorang. Secara umum, objek sikap yang perlu dinilai dalam proses pembelajaran adalah: (1) sikap terhadap materi pelajaran; (2) sikap terhadap pengajar atau pengajar; (3) sikap terhadap proses pembelajaran; dan (4) sikap berkaitan dengan nilai atau norma yang berhubungan dengan suatu materi pelajaran.

\section{B. HASIL PENELITIAN DAN PEMBAHASAN}

\section{Hasil Penelitian}

Pelaksanaan tindakan penelitian terdiri atas tiga siklus yang dilakukan padabulan Februari s.d. Oktober 2020. Proses pembelajaran penelitian tindakan kelas terdiri atas kegiatan awal, inti,dan akhir. Adapun "hal-hal yang akan dievaluasi dalam penilaian proses membaca yaitu pelafalan, intonasi, kelancaran, dan pemahaman" membaca kalimat dengan aksara Lampung. Hal lain yang akan dievaluasi adalah mengamati penerapan model pembelajaran literasi informasi. Hasil penelitian menunjukkan persentase ketuntasan penilaian proses kemampuan membaca kalimat dengan aksara Lampung 
peserta didik meningkat di setiap siklus. Dari hasil pengamatan berkaitan dengan penerapan model pembelajaran literasi informasi bila dilakukan dengan baik akan membuat peserta didik maksimal dalam belajar dan hasil belajar pun akan meningkat.

Hasil penelitian menunjukkan bahwa persentase ketuntasan penilaian proses kemampuan membaca kalimat dengan aksara Lampung dan penerapan model pembelajaran literasi informasi peserta didik, meningkat di setiap siklus, yaitu siklus $1-3$. Di bawah ini akan dijelaskan hasil pelaksanaan penelitian yang dimulai dari siklus 1 s.d 3 .

Tabe11. Persentase Penilaian Kemampuan Membaca Kalimat dengan Aksara Lampung Siswa Kelas IV SD Negeri 04 Kotabumi Tahun Pelajaran 2020/2021 Siklus IIII

\begin{tabular}{|c|c|c|c|}
\hline \multicolumn{2}{|c|}{ Persentase Penilaian } & Keteranga \\
Kemampuan & n \\
Membaca & $3=$ & \\
$1=$ & $2=$ & Meningkat \\
$70 \%$ & $85 \%$ & $98 \%$ & siklus \\
$(22$ & $(26$ & $(30$ & \\
siswa & siswa & siswa & \\
) & ) & ) & \\
\hline
\end{tabular}

Tabel 2. Persentase Penerapan Model
Pembelajaran Literasi Informasi Siswa Kelas IV SD Negeri 04 Kotabumi Tahun Pelajaran 2020/2021 Siklus I-III

\begin{tabular}{|c|c|c|c|}
\hline \multicolumn{3}{|c|}{$\begin{array}{l}\text { Persentase Penerapan } \\
\text { Model Pemb. Literasi }\end{array}$} & Keterangan \\
Informasi & \\
\hline siklus & siklus & siklus & \\
$1=$ & $2=$ & $3=$ & meningkat \\
$70 \%$ & $83 \%$ & $95 \%$ & \\
\hline
\end{tabular}

Data dari tabel 1 di atas menggambarkan bahwa hasil penelitian yang telah dilakukan pada siklus ke-1 terdapat 22 atau $70 \%$, siklus ke- 2 terdapat 26 atau $85 \%$, dan siklus ke-3 terdapat 30 atau 98\% peserta didik yang kemampuan membaca dengan aksara Lampung telah mencapai nilai KKM yang telah ditetapkan, yaitu sebesar 70. Nilai yang diperoleh peserta didik adalah nilai olahan saat proses pembelajaran berlangsung dan pada tiap siklusnya selalu ada peningkatan.

Data pada tabel 2 mennggambarkan persentase penerapan model pembelajaran literasi informasi yang diberikan pada peserta didik. Pada siklus kedua, persentase penerapan model pembelajaran literasi informasi yang diberikan pada peserta didik baru mencapai 70\%, siklus kedua $83 \%$, dan pada siklus ketiga 95\%. Dari tindakan yang sudah dilakukan, terdapat peningkatkan proses belajar dan 
Peningkatan Kemampuan Membaca Kalimat dengan Aksara Lampung melalui Penerapan Model Pembelajaran Literasi Informasi Siswa Kelas IV SD Negeri 04 Tanjung Aman Kotabumi Tahun Pelajaran 2020/2021 (Masitoh)

kemampuan membaca kalimat dengan aksara Lampung peserta didik melalui penerapan model pembelajaran literasi informasi siswa kelas IV SDNegeri 04 Kotabumi tahun pelajaran 2020/2021. Penerapan model pembelajaran literasi informasi bila dilakukan dengan baik akan membuat peserta didik maksimal dalam belajar dan hasil belajar pun akan meningkat.

\section{Pembahasan}

Hasil penelitian menunjukkan bahwa persentase ketuntasan penilaian kemampuan membaca kalimat dengan aksara Lampung dan penerapan model pembelajaran literasi informasi peserta didik, meningkat di setiap siklus, yaitu siklus 1-3. Dari tindakan yang sudah dilakukan, terdapat peningkatkan proses belajar dan kemampuan membaca kalimat dengan aksara Lampung melalui penerapan model pembelajaran literasi informasi siswa selas IV SD Negeri 04 Kotabumi tahun pelajaran 2020/2021. Penerapan model pembelajaran literasi informasi bila dilakukan dengan baik akan membuat peserta didik maksimal dalam belajar dan hasil belajar pun akan meningkat.

Model pembelajaran literasi informasi menuntut agar peserta didik belajar dengan aktif dan mencari bahan materi pelajaran dari berbagai sumber.
Hal ini sejalan dengan pendapat Sigmon yang dikutip Kusuma (2010) yang menyatakan bahwa model pembelajaran literasi informasi memiliki pengaruh yang lebih baik dalam mengembangkan kemampuan peserta didik.

\section{SIMPULAN DAN SARAN}

\section{Simpulan}

Persentase ketuntasan penilaian kemampuan membaca kalimat dengan aksara Lampung dan penerapan model pembelajaran literasi informasi peserta didik, meningkat di setiap siklus. Dari tindakan yang sudah dilakukan, penerapan model pembelajaran literasi informasi dapat meningkatkan proses belajar dan kemampuan membaca kalimat dengan aksara Lampung peserta didik kelas IV SD Negeri 04 Kotabumi tahun pelajaran 2020/2021. Penerapan model pembelajaran literasi informasi bila dilakukan dengan baik akan membuat peserta didik maksimal dalam belajar dan hasil belajar pun akan meningkat.

Model pembelajaran literasi informasi menuntut agar peserta didik belajar dengan aktif dan mencari bahan materi pelajaran dari berbagai sumber. Model pembelajaran literasi informasi memiliki pengaruh yang lebih baik dalam mengembangkan kemampuan peserta didik. 


\section{Saran}

Ada beberapa saran yang ditujukan untuk peserta didik, guru, dan pembaca.

(1) Siswa diharapkan dapat memaksimalkan kemampuan membaca kalimat dengan aksara Lampung.

pembelajaran literasi informasi untuk meningkatkan kemampuan membaca kalimat dengan aksara Lampung peserta didik.

(3) Untuk pembaca,semoga hasil penelitian ini bisa digunakan sebagai alternatif sumber rujukan atau referensi untuk melakukan penelitian lanjutan.

(2) Guru dapat menggunakan model

\section{DAFTAR PUSTAKA}

Agustina, E. S. (2016). Penguasaan Kosakata Bahasa Lampug melalui Lagu Anak-Anak Populer untuk Tingkat Pendidikan Dasar. . (pp. 165-184). Lampung: FKIP UNILA.

Alwi, H. S. (2003). Tata Bahasa Baku Bahasa Indonesia. Jakarta: Balai Pustaka.

Arikunto, S. S. (2011). Penelitian Tindakan Kelas. Jakarta: Bumi Aksara.

Kusuma, S. (2010). Model Pembelajaran Siswa Aktif. Jakarta: Sketsa Aksara.

Masitoh. (2010). Unsur-Unsur Fonologi Bahasa Lampung Dialek O Abung. Lampung: Sekolah Tinggi Keguruan dan Ilmu Pendidikan Muhammadiyah Kotabumi.

Sumarno, I. S. (2020). Pedoman Penulisan Karya Ilmiah. Kotabumi: Universitas Muhammadiyah Kotabumi.

Suwandi. (2011). Model-Model Asesmen dalam Pembelajaran. Surakarta: Yuma Pustaka.

Suwandi, S. (2011). Penelitian Tindakan Kelas dan Penulisan Karya Ilmiah. Surakarta: Yuma Pustaka.

Tarigan, H. G. (2010). Membaca sebagai Suatu Keterampilan . Bandung: Angkasa.

Winarno. (2020, September 23). Pelajaran Bahasa Lampung dan Bahan Tanya Jawab untuk . Retrieved from Scribd.com: https://www.scribd.com/document/403117206 